\title{
Original article: \\ Recent cockroach bacterial contamination trend in the human dwelling environments: A systematic review and meta-analysis \\ Hassan Nasirian
}

\begin{abstract}
:
Background: Cockroaches have been compromised with the human environment posing some risks to humans. Objective: A systematic review and meta-analysis study about the bacterial contamination of cockroaches in the human dwelling environmentswere investigated. Methodology: Relevant topics about bacterial contamination of cockroaches were collected from scientific websites between January 2016 and January 2017. After a preliminary review 32 of the collected topics were selected to become part of the detailed synthesis meta-analysis review. Results: Results showed that the global mean bacterial contamination trend of cockroaches and Periplaneta americana ranged 45.0-80.0 and 55.0-75.0\%, respectively which were increased while it were $90.0-50.0 \%$ for Blattella germanica which decreased in recent years. The global mean bacterial contamination of cockroaches, $P$. americana and $B$. germanica was also 67.9, 72.9 and $62.9 \%$, respectively which P. Americana had the most global mean bacterial contamination. Statistical analysis didn't show any significant differences between any combination of bacterial contamination of the cockroaches, and $P$. americana and $B$. germanica surfaces such as totalexternal, total-internal and external-internal; any type environment of cockroaches, $P$. americana and $B$. germanica including households, hospitals and miscellaneous; any combination of bacterial contamination such as between total-total, external-external and internal-internal surfaces of the P. americana and $B$. germanica; and P. americana and B. germanica in combination environments of households-households, hospitals-hospitals and miscellaneous-miscellaneous $(\mathrm{P}>0.05)$. Conclusions: The external and internal surfaces of any type cockroach have equal importance ofbacterial contamination and they threaten human health in the any type environment.
\end{abstract}

Keywords: Blattella germanica; Cockroaches; Cockroach bacterial contamination trend; Nosocomial infection; Periplaneta americana

Bangladesh Journal of Medical Science Vol. 18 No. 03 July'19. Page : 540-545 DOI: https://doi.org/10.3329/bjms.v18i3.41623

\section{Introduction}

Cockroaches have been adapted with the human life environments including hospitals ${ }^{1-16}$. They can pose some risks to humans such as transfer of pathogens to humans which may cause serious illness. The infections that the patients obtained in the hospitals are named as nosocomial infections. As cockroaches are being harbor of pathogenic organisms and move freely from areas within hospitals, they are considered as transmitter of nosocomial infection at hospital environments ${ }^{17-21}$.

Some researchers have reported cockroach bacterial contamination e. g. Pai et al. (2004), Salehzadeh et al. (2007), Lin et al. (2008), Al-bayati et al. (2011), Kassiri and Kazemi (2012), Zacharia et al. (2013) and Wannigama et al. (2014) $22-28$. But in this regard there is no a global comprehensive study about cockroach bacterial contamination. Therefore a systematic review and meta-analysis study about the contamination of cockroaches (Insecta: Blattaria) to bacteria in the human building environmentswere investigated.

\section{Materials and methods}

\section{Data collection and selection}

Relevant topics, papers and scientific notes about contamination of cockroaches were collected from various websites such as Google Scholar, specific scientific sites, Scopus, PubMed, Web of Science, Elsevier and Springer, as well as Science Direct, between January 2016 and January 2017. About 249 papers and scientific notes were collected from the mentioned addresses and after a preliminary review, 44 were selected to become part of the detailed synthesis review and meta-analysis.

\section{Data meta-analysis}

The papers and scientific notes about contamination

Correspondence to: Dr. Hassan Nasirian, Department of Medical Entomology and Vector Control, School of Public Health, Tehran University of Medical Sciences, Tehran, Iran, E-mail: hanasirian@yahoo.com 
of cockroaches to bacteria were read carefully and the useful subjects were extracted and sorted. Bacterial contamination of cockroaches mainly categorized into three parts including hospitals, households and miscellaneous environments. As the hospitals and households are the important human dwelling environments, the cockroach bacterial contamination categorized into two these distinct parts, while the other type of cockroach bacterial contamination was arranged in the miscellaneous part. The results summarized in the table 1 .

\section{Statistical analysis}

The global bacterial contaminationt rend of cockroaches, and Periplaneta americana and Blattella germanica cockroach species were calculated and estimated by Microsoft Excel 2010. The global trend cockroach fungal contamination was drawn by clicking on graph line distribution and selecting "add trendline" option. The global cockroach fungal contamination was calculated by insertion function and selecting "average" option. Fig. 1 shows the global bacterial contamination trend of cockroaches, and Periplaneta americana and Blattella germanica cockroach species. IBM SPSS Statistics Data Editor Version 23 was used to analyze any statistical analysis of the data. Onesample Kolmogorov-Smirnov testwas used to check the normality of the data distribution. After checking to make sure that the distribution of data was normal, paired-samples $t$-test was used to compare contamination of cockroaches between two groups, while ANOVA was used to compare contamination of cockroaches among more than two groups including the hospital, householdand miscellaneous environments for any significant difference. Table 2 shows statistical analysis of bacterial contamination of cockroaches, and Periplaneta americana and Blattella germanica cockroach species.

Ethical clearance: The study was approved by Ethics Committee of School of Public Health, Tehran University of Medical Sciences, Tehran, Iran

\section{$\underline{\text { Results }}$}

\section{Cockroach bacterial contamination trend}

The results of cockroach bacterial contamination were summarized in the table 1 . The global mean bacterial contamination trend of cockroaches from 2003 to 2014 was increased ranged from 45.0 to 80.0 $\%$. The global mean bacterial contamination trend of Periplaneta americana cockroaches from 2003 to 2014 was increased ranged from 55.0 to $75.0 \%$. The global mean bacterial contamination trend of Blattella germanica cockroaches from 2004 to 2014 was decreased ranged from 90.0 to $50.0 \%$ (Fig. 1).

\section{Cockroach global mean bacterial contamination}

The global mean bacterial contamination of cockroaches was $67.9 \%$. The global mean bacterial contamination of $P$. americana cockroaches was 72.9 $\%$.The global mean contamination of $B$. germanica cockroaches was $62.9 \%$ (Fig. 1).

\section{Cockroach body part bacterial contamination analysis}

There was no any significant differences between any combination of bacterial contamination such as between total-external, total-internal and externalinternal surfaces of cockroaches, and P.americana and B.germanica cockroach species $(\mathrm{P}>0.05)$ except between total-internal and external internal-internal surfaces of $B$. germanica cockroaches $(\mathrm{P}=0.031)$. There was also no any significant differences between any combination of bacterial contamination such as between total-total, external-external and internal-internal surfaces of the P. americana and $B$. germanica cockroach species $(\mathrm{P}>0.05)$ (Table 2).

\section{Discussion}

Like pediculosis, scabies, myiasis and tick-borne diseases $^{36-40}$, cockroaches are threating human health ${ }^{17-21,41,42}$. Present study shows that the global mean bacterial contamination trend of cockroaches, Periplaneta american (American cockroach) and Blattella germanica (Germanco ckroach) cockroach species from 2003 to 2014 ranged 45.0-80.0, 55.075.0 and $90.0-50.0 \%$, respectively. The global mean bacterial contamination trend of cockroaches and American cockroach species were increased during 2003 to 2014 whiledecreased for German cockroach species during 2004 to 2014 (Fig. 1). The global mean bacterial contamination of cockroaches, American and German cockroach species was also 67.9, 72.9 and 62.9\%, respectively which American cockroach species $(72.9 \%)$ had the most global mean bacterial contamination. Statistical analysis didn't show any significant differences between bacterial contamination of cockroaches, and American and German cockroach species $(\mathrm{P}>0.05)$ (Table 2) suggests that the cockroaches, and American and German cockroach species have the same importance of bacterial contamination.

Statistical analysis didn't show any significant 
differences between any combination of bacterial contamination such as between total-external, total-internal and external-internal surfaces of the cockroaches, and American and German cockroach species $(\mathrm{P}>0.05)$ except between total-internal and external internal-internal surfaces of German cockroach species $(\mathrm{P}=0.031)$. There was no any significant differences between any combination of bacterial contamination such as between totaltotal, external-external and internal-internal surfaces of the American and German cockroach species $(\mathrm{P}>0.05)$ (Table 2). These facts suggest that the external-internal, external and internal surfaces of cockroaches, and American and German cockroaches have equal importance of bacterial contamination.

Statistical analysis didn't show any significant differences between bacterial contamination of any type environment (such as households, hospitals and miscellaneous) of cockroaches, American and German cockroache species ( $\mathrm{P}>$ 0.05) (Table 2). Statistical analysis also didn't show any significant differences between bacterial contamination of American and German cockroach species in combination environments of householdshouseholds, hospitals-hospitals and miscellaneousmiscellaneous $(\mathrm{P}>0.05)$ (Table 2$)$. These facts suggest that the cockroaches, andAmerican and German cockroach species threaten human health in the any type environment. Although a variety of disease agents can be currently spread by cockroaches, while it is possible to determine cockroach transmitting ability of the disease agents that they are not capable to transmit them by artificially contamination of cockroaches ${ }^{43-44}$.

\section{Conclusion}

Cockroaches have been compromised with the human life environments. As cockroaches are being harbor of pathogenic organisms and move freely from areas within hospitals, they are considered as transmitter of nosocomial infection at hospital environments. A systematic meta-analysis review about cockroach bacterial contamination in the human dwelling environments was investigated. The results indicate that the global mean bacterial contamination trend of cockroaches were increased in recent years. The global mean bacterial contamination of cockroaches, P. americana and B. germanica cockroach species was $67.9,72.9$ and $62.9 \%$, respectively which P. americana $(72.9 \%)$ had the most global mean bacterial contamination. Statistical analysis didn't show any significant differences between cockroaches, and $P$. americana and B. germanica cockroach surfacesand any environment type (such as households, hospitals and miscellaneous) of cockroach bacterial contamination $(\mathrm{P}>0.05)$. These facts suggest that external and internal surfaces of cockroaches, and $P$. americana and $B$. germanica cockroach species have equal importance of bacterial contamination and they threaten human health in the any type environment.

\section{Acknowledgments}

This work did not receive any technical or financial support from any institution and was done by the author at his own personal expense.

\section{Conflict of interest: None}

\section{Author's contribution:}

Data gathering and idea owner of this study, Study design, Data gathering, Writing and submitting manuscript: Editing and approval of final draft, all events have done by Hassan Nasirian

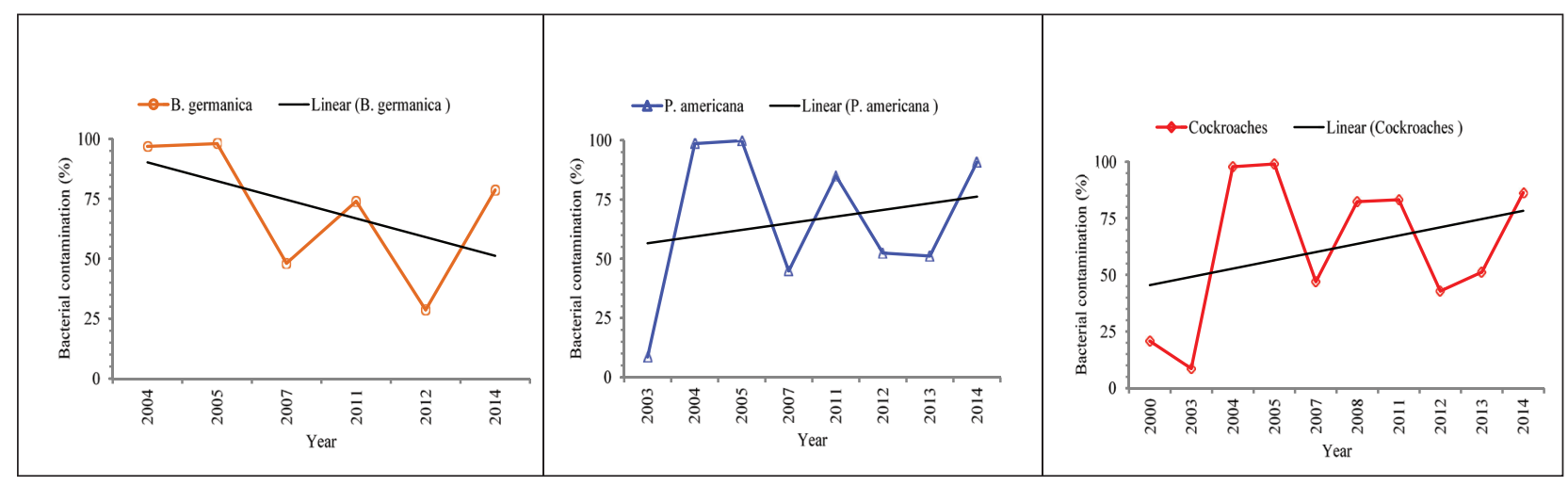

Fig. 1 Global world bacterial contamination of cockroaches and cockroach species 
Table. 1 Thebacterial contamination of cockroaches

\begin{tabular}{|c|c|c|c|c|c|}
\hline Cockroach & Contamination & & Environment & Place & Reference \\
\hline & Body part & $\%$ & & & \\
\hline Cockroaches & External surface and alimentary tract & 20.8 & Hospitals & South Africa & (29) \\
\hline P. americana & External surface and alimentary tract & 8.63 & Hospitals & Taiwan & (30) \\
\hline P. americana & External surface and alimentary tract & 98.6 & Hospitals & Taiwan & (22) \\
\hline B. germanica & External surface and alimentary tract & 96.9 & Hospitals & Taiwan & (22) \\
\hline P. americana & External surface and alimentary tract & 99.9 & Households & Taiwan & (22) \\
\hline B. germanica & External surface and alimentary tract & 98.0 & Households & Taiwan & (22) \\
\hline P. americana & External surface & 67.0 & Hospitals & Iran (Sanandaj) & (31) \\
\hline P. americana & Alimentary tract & 22.8 & Hospitals & Iran (Sanandaj) & (31) \\
\hline B. germanica & External surface and alimentary tract & 4.5 & Households & Iran (Hamadan) & (23) \\
\hline B. germanica & External surface and alimentary tract & 98.0 & Hospitals & Iran (Hamadan) & (23) \\
\hline B. germanica & External surface & 67.0 & Hospitals & Iran (Sanandaj) & (31) \\
\hline B. germanica & Alimentary tract & 22.8 & Hospitals & Iran (Sanandaj) & (31) \\
\hline Cockroaches & External surface and alimentary tract & 82.4 & Cities & China (Hainan) & (24) \\
\hline P. americana & External surface & 100 & Hospitals & Iraq (Diyala) & (25) \\
\hline P. americana & External surface & 83.3 & Houses around hospitals & Iraq (Diyala) & (25) \\
\hline P. americana & External surface and alimentary tract & 74.0 & Households & Iran (Sanandaj) & (32) \\
\hline P. americana & Alimentary tract & 72.7 & Houses around hospital & Iraq (Diyala) & (25) \\
\hline P. americana & Alimentary tract & 95.0 & Hospitals & Iraq (Diyala) & (25) \\
\hline B. germanica & External surface and alimentary tract & 74.0 & Residential dwellings & Iran (Sanandaj) & (32) \\
\hline P. americana & Alimentary tract & 30.8 & Hospitals & Iran (Hamedan) & (33) \\
\hline P. americana & External surface & 100 & Health andmedicalcenters & Iran & (26) \\
\hline P. americana & External surface & 26.5 & Hospitals & Iran (Hamedan) & (33) \\
\hline B. germanica & External surface & 26.5 & Hospitals & Iran (Hamedan) & (33) \\
\hline B. germanica & Alimentary tract & 30.8 & $\begin{array}{l}\text { Hospitals } \\
\text { Hospitals, domestic }\end{array}$ & Iran (Hamedan) & (33) \\
\hline P. americana & Alimentary tract & 51.2 & environments, market places & India & (27) \\
\hline & & 900 & $\begin{array}{l}\text { and restaurants } \\
\text { Hospitals }\end{array}$ & Iran & \\
\hline $\begin{array}{l}\text { P. americana } \\
\text { P. americana }\end{array}$ & $\begin{array}{l}\text { External surrace } \\
\text { External surface }\end{array}$ & 100 & $\begin{array}{l}\text { Hospitals } \\
\text { Households }\end{array}$ & $\begin{array}{l}\text { Iran } \\
\text { Iran (Ahvaz) }\end{array}$ & $\begin{array}{l}(34) \\
(35)\end{array}$ \\
\hline P. americana & External surface & 64.0 & Households and food- & India (Varanasi) & $(28)$ \\
\hline P. americana & External surface & 100 & $\begin{array}{l}\text { handling establishments } \\
\text { Households }\end{array}$ & India (Varanasi) & (28) \\
\hline P. americana & External surface & 100 & Food- handling establishments & India (Varanasi) & (28) \\
\hline B. germanica & External surface & 36.0 & Households and food- & India (Varanasi) & $(28)$ \\
\hline B. germanica & External surface & 100 & $\begin{array}{l}\text { handling esta } \\
\text { Households }\end{array}$ & India (Varanasi) & (28) \\
\hline B. germanica & External surface & 100 & Food- handling establishments & India (Varanasi) & (28) \\
\hline
\end{tabular}

Table. 2 Statistical analysis of cockroachbacterial contamination

\begin{tabular}{|c|c|c|c|c|c|}
\hline Analysis of cockroach bacterial contamination & $\begin{array}{l}\text { Std. } \\
\text { deviation }\end{array}$ & Std. error mean & $\mathbf{t}$ & df & $\begin{array}{l}\text { Sig. } \\
\text { (2-tailed) }\end{array}$ \\
\hline \multicolumn{6}{|l|}{ Cockroaches } \\
\hline Between total-external internal & 39.7 & 12.0 & 0.559 & 10 & 0.589 \\
\hline Between total-external & 49.5 & 12.8 & 0.989 & 14 & 0.340 \\
\hline Between total-internal & 33.1 & 12.5 & 1.867 & 6 & 0.111 \\
\hline Between external internal-external & 34.7 & 10.5 & 0.596 & 10 & 0.564 \\
\hline Between external internal-internal & 42.6 & 16.1 & 0.898 & 6 & 0.404 \\
\hline Between external-internal & 34.7 & 13.1 & 1.569 & 6 & 0.168 \\
\hline Between households-hospitals & 48.9 & 14.8 & 1.259 & 10 & 0.237 \\
\hline Between households-miscellaneous & 48.9 & 14.8 & 1.259 & 10 & 0.237 \\
\hline \multicolumn{6}{|l|}{ P. americana } \\
\hline Between total-external internal & 3.5 & 1.8 & 1.000 & 3 & 0.391 \\
\hline Between total-external & 35.7 & 11.3 & 0.504 & 9 & 0.626 \\
\hline Between total-internal & 53.6 & 24.0 & 0.848 & 4 & 0.444 \\
\hline Between external internal-external & 43.3 & 21.7 & 0.143 & 3 & 0.895 \\
\hline Between external internal-internal & 60.1 & 30.1 & 0.498 & 3 & 0.653 \\
\hline Between external-internal & 35.6 & 15.9 & 1.393 & 4 & 0.236 \\
\hline Between households-hospitals & 42.9 & 16.2 & 0.909 & 6 & 0.399 \\
\hline Between households-miscellaneous & 13.7 & 5.2 & 1.348 & 6 & 0.226 \\
\hline Between hospitals-miscellaneous & 48.1 & 17.0 & 0.969 & 7 & 0.365 \\
\hline \multicolumn{6}{|l|}{ B. germanica } \\
\hline Between total-external internal & 3.1 & 1.4 & 1.000 & 4 & 0.374 \\
\hline Between total-external & 44.3 & 19.8 & 0.352 & 4 & 0.742 \\
\hline Between total-internal & 4.9 & 3.4 & 20.478 & 1 & 0.031 \\
\hline Between external internal-external & 42.8 & 19.1 & 0.438 & 4 & 0.684 \\
\hline Between external internal-internal & 4.9 & 3.5 & 20.478 & 1 & 0.031 \\
\hline Between external-internal & 34.3 & 24.3 & 0.823 & 1 & 0.562 \\
\hline Between households-hospitals & 60.9 & 27.2 & 0.009 & 4 & 0.993 \\
\hline Between households-miscellaneous & 69.2 & 30.9 & 0.013 & 4 & 0.990 \\
\hline Between hospitals-miscellaneous & 73.2 & 32.7 & 0.020 & 4 & 0.985 \\
\hline \multicolumn{6}{|l|}{$P$. americana and $B$. germanica } \\
\hline Between total-total & 58.1 & 16.8 & 0.826 & 11 & 0.426 \\
\hline Between external internal-external internal & 76.2 & 38.1 & 0.106 & 3 & 0.922 \\
\hline Between external-external & 60.0 & 26.8 & 0.402 & 4 & 0.708 \\
\hline Between internal-internal & 40.9 & 28.9 & 0.724 & 1 & 0.601 \\
\hline Between households-households & 39.8 & 17.8 & 1.321 & 4 & 0.257 \\
\hline Between hospitals-hospitals & 61.0 & 24.9 & 0.393 & 5 & 0.710 \\
\hline Between miscellaneous-miscellaneous & 54.9 & 24.6 & 0.941 & 4 & 0.400 \\
\hline
\end{tabular}




\section{References:}

1. Nasirian H, Ladonni H, Vatandoost H. Duration of fipronil topical application toxicity in Blattella germanica field population strains. Pakistan J Biol Sci 2006;9:800-804.

2. Nasirian H, Ladonni $H$, Vatandoost $H$, Shayeghei $M$, Poudat A. Laboratory performance of $0.05 \%$ fipronil and $2.15 \%$ imidacloprid gel baits against German cockroaches, Blattella germanica. Hormozgan Med. J 2006;10:24-25.

3. Nasirian H, Ladonni H, Shayeghi M, Vatandoost H, Rassi Y, Ershadi MY, et al. Duration of fipronil WHO glass jar method toxicity against susceptible and feral German Cockroach strains. Pak. J. Biol. Sci 2006;9:1955-1959.

4. Nasirian H. Duration of fipronil and imidacloprid gel baits toxicity against Blattella germanica strains of Iran. Journal of Arthropod-Borne Diseases 2007;1(2):40-47.

5. Nasirian H. Rapid elimination of German Cockroach, Blattella germanica, by fipronil and imidacloprid gel baits. Journal of Arthropod-Borne Diseases 2008;2(1):37-43.

6. Nasirian H, Ladonni H, Shayeghi M, Ahmadi MS. Iranian non-responding contact method German cockroach permethrin resistance strains resulting from field pressure pyrethroid spraying. Pak J Biol Sci 2009;12(8):643-7.

7. Limoee M, Shayeghi M, Heidari J, Nasirian H, Ladonni H. Susceptibility level of hospital-collected strains of German cockroach Blattella germanica (L.) to carbamate and organophosphorous insecticides using surface contact method in Tehran (2007-2008). Journal of Kermanshah University of Medical Sciences ( $J$ Kermanshah Univ Med Sci) 2010;13(4):337-343.

8. Nasirian H. An overview of German cockroach, Blattella germanica, studies conducted in Iran. Pak J Biol Sci 2010;13(22):1077-84.

9. Paksa A, Ladonni H, Nasirian H. Detection of malathion and chlorpyrifos resistance mechanism in German cockroaches (Blattella germanica, Insecta: Blattodea: Blattellidae) using piperonyl butoxide and tributyl phosphorotrithioate. Bimonthly Journal of Hormozgan University of Medical Sciences 2011;15(3):243-253.

10. Nasirian H, Ladonni H, Aboulhassani M, Limoee M. Susceptibility of field populations of Blattella germanica (Blattaria: Blattellidae) to spinosad. Pak J Biol Sci 2011;14(18):862-8.

11. Paksa A, Ladonni H, Nasirian H. Comparison of PBO and DEF effects on creating bendiocarb and carbaryl insecticide resistance in German cockroach. Scientific Journal of Kurdistan University of Medical Sciences 2012;17(3):91-101.

12. Ladonni H, Paksa A, Nasirian H, Doroudgar A, Abaie M. Detection of Carbamat and organo phosphorus susceptibility levels in German cockroach in vivo. Toloo e Behdasht 2013;40(3):95-105.

13. Dehghani R, Atharizadeh M, Moosavi SG, Azadi S, Rashidi M, Paksa A. Analysis of cockroach fauna and frequency in human residential habitats of North of Isfahan, Iran. International Archives of Health Sciences 2014;1(1):25-29.

14. Nazari M, Alipourian Motlagh B, Nasirian H. Toxicity of cypermethrin and chlorpyrifos against German cockroach [Blattella germanica (Blattaria: Blattellidae)] strains from Hamadan, Iran. Pakistan Journal of Biological Sciences 2016;19(6):259-264.

15. Sanei Dehkordi A, Salim Abadi Y, Nasirian H, Hazratian T, Gorouhi MA, Yousefi S, et al. Synergists action of piperonyl butoxide and S,S,S-tributyl phosphorotrithioate on toxicity of carbamate insecticides against Blattella germanica. Asian Pacific Journal of Tropical Medicine 2017;10(10):981-986.

16. Nasirian H, Ladonni H, Shayeghi M, Vatandoost $H$, Yaghoobi-Ershadi M, Rassi Y, et al. Comparison of permethrin and fipronil toxicity against German cockroach (Dictyoptera: Blattellidae) strains. Iranian Journal of Public Health 2006;35(1):63-67.

17. Scherbaum M, Kösters K, Mürbeth RE, Ngoa UA, Kremsner PG, Lell B, et al. Incidence, pathogens and resistance patterns of nosocomial infections at a rural hospital in Gabon. BMC infectious diseases 2014;14(1):124.

18. Mikulak E, Gliniewicz A, Pancer K, StypułkowskaMisiurewicz H, Rabczenko D, Królasik A. Microbiological hazard for patients caused by bacteria present on synantropic arthropods in hospital environment. Microbial pathogens and strategies for combating them: science, technology and education 2013:1770-1777.

19. Sabra SM, Abdel-Fattah MM. Epidemiological and microbiological profile of nosocomial infection in Taif hospitals, KSA (2010-2011). World Journal of Medical Sciences 2012;7(1):1-9.

20. Nasirian H. Contamination of cockroaches (Insecta: Blattaria) to medically fungi: A systematic review and meta-analysis. Journal de Mycologie Médicale/Journal of Medical Mycology 2017;27(4): 427-448.

21. Davari B, Hassanvand A, Nasirian H, Ghiasian S, Salehzadeh A, Nazari M. Comparison of cockroach fungal contamination in the clinical and non-clinical environments from Iran. Journal of Entomological and Acarological Research 2017;49(2):109- 115.

22. Pai HH, Chen WC, Peng CF. Cockroaches as potential vectors of nosocomial infections. Infect Control Hosp Epidemiol 2004;25(11):979-84.

23. Salehzadeh A, Tavacol P, Mahjub H. Bacterial, fungal and parasitic contamination of cockroaches in public hospitals of Hamadan, Iran. J Vector Borne Dis 2007;44(2):105-10.

24. Lin YZ, Cui YB, Yang W, Rao LY, Pan W, Chen JL. [Investigation on species composition of cockroaches 
Recent cockroach bacterial contamination trend in the human dwelling environments: A systematic review and meta-analysis

and bacteria-carrying on their bodies in five cities of Hainan]. Zhongguo Ji Sheng Chong Xue Yu Ji Sheng Chong Bing Za Zhi 2008;26(1):77-8.

25. Al-bayati NY, Al-Ubaidi AS, Al-Ubaidi IK. Risks associated with cockroach Periplaneta americana as a transmitter of pathogen agents. Diyala Journal of Medicine 2011;1(1):91-97.

26. Kassiri H, Kazemi S. Cockroaches [Periplaneta americana (L.), Dictyoptera; Blattidae] as carriers of bacterial pathogens, Khorramshahr County, Iran. Jundishapur Journal of Microbiology 2012;5(1):320-322.

27. Zacharia S, Peter A, Mathew J, Radhakrishnan EK. Periplaneta americana as an intestinal carrier of nosocomial and food borne bacterial pathogens Asian Journal of Pharmaceutical and Clinical Research 2013;6(4):38-41

28. Wannigama DL, Dwivedi R, Zahraei-Ramazani A. Prevalence and Antibiotic Resistance of Gram-Negative Pathogenic Bacteria Species Isolated from Periplaneta americana and Blattella germanica in Varanasi, India. $J$ Arthropod Borne Dis 2014;8(1):10-20.

29. Cotton MF, Wasserman E, Pieper $\mathrm{CH}$, Theron DC, van Tubbergh D, Campbell G, et al. Invasive disease due to extended spectrum beta-lactamase-producing Klebsiella pneumoniae in a neonatal unit: the possible role of cockroaches. J Hosp Infect 2000;44(1):13-7.

30. Pai HH, Chen WC, Peng CF. Isolation of non-tuberculous mycobacteria from hospital cockroaches (Periplaneta americana). J Hosp Infect 2003;53(3):224-8.

31. Vahabi A, Rafinejad J, Mohammadi P, Biglarian F. Regional evaluation of bacterial contamination in hospital environment cockroaches. Iranian Journal of Environmental Health Science \& Engineering 2007;4(1):57-60.

32. Vahabi A, Shemshad K, Mohammadi P, Sayyadi M, Shemshad M, Rafinejad J. Microbiological study of domestic cockroaches in human dwelling localities. Afr J Microbiol Res 2011;5:5790-5792.

33. Nejati J, Keyhani A, Moosa-Kazemi SH, Mohammadi M, Mahjoob M, Boostanbakhsh A. Cockroaches' bacterial infections in wards of hospitals, Hamedan city, west of Iran. Asian Pacific Journal of Tropical Disease 2012;2(5):381-384.

34. Kassiri H, Kassiri A, Kazemi S. Investigation on American cockroaches medically important bacteria in Khorramshahr hospital, Iran. Asian Pacific Journal of
Tropical Disease 2014;4(3):201-203.

35. Kassiri H, Quaderi A. Detection and prevalence rate of American cockroaches bacterial infections in human dwellings, south western Iran. Iranian Journal of Public Health 2014;43(2):190.

36. Poudat A, Nasirian H. Prevalence of pediculosis and scabies in the prisoners of Bandar Abbas, Hormozgan province, Iran. Pak J Biol Sci 2007;10(21):3967-9.

37. Ahmadi MS, Nasirian H, Gheshmi AN, Ershadi MY. Human extensive head Skin myiasis. Iranian Journal of Public Health 2009;38(1):134-138.

38. Telmadarraiy Z, Nasirian H, Vatandoost H, Abuolhassani M, Tavakoli M, Zarei Z, et al. Comparative susceptibility of cypermethrin in Ornithodoros lahorensis Neuman and Argas persicus Oken (Acari: Argasidae) field populations. Pak J Biol Sci 2007;10(23):4315-8.

39. Shayeghi M, Piazak N, Gollampuor A, Nasirian H, Abolhassani M. Tick-borne relapsing fever in Sabzevar (Khorasan Razavy Province), North-Eastern Iran. Bangladesh Journal of Medical Science 2016;15(4):551-555.

40. Davari B, Alam FN, Nasirian H, Nazari M, Abdigoudarzi M, Salehzadeh A. Seasonal distribution and faunistic of ticks in the Alashtar county (Lorestan Province), Iran. Pan African Medical Journal 2017;27(284):1-16.

41. Nasirian H. New aspects about Supella longipalpa (Blattaria: Blattellidae). Asian Pacific Journal of Tropical Biomedicine 2016;6(12):1065-1075.

42. Davari B, Kashani S, Nasirian H, Nazari M, Salehzadeh A. The efficacy of MaxForce and Avion gel baits containing fipronil, clothianidin and indoxacarb against the German cockroach (Blattella germanica) Entomological Research 2018;48:https://doi. org/10.1111/1748-5967.12282.

43. Nasirian H, Ladonni H, Poudat A. Mass rearing of Anophelesstephensi on human blood by artificial feeding under laboratory conditions. Bimonthly Journal of Hormozgan University of Medical Sciences 2008;12(3):137-142.

44. Nasirian H, Ladonni H. Artificial bloodfeeding of Anopheles stephensi on a membrane apparatus with human whole blood. J Am Mosq Control Assoc 2006;22(1):54-6. 